\title{
Role of oral pathogens in the pathogenesis of intracranial aneurysm: review of existing evidence and potential mechanisms
}

\author{
Joona Hallikainen ${ }^{1,2,3,7}$ (1) - Sara Keränen ${ }^{3}$. Jarno Savolainen ${ }^{1,2} \cdot$ Matti Närhi ${ }^{1,4} \cdot$ Anna Liisa Suominen $^{1,2,5}$ • \\ Pekka Ylöstalo $^{6}$ • Jari Kellokoski ${ }^{1,2} \cdot$ Mikko Pyysalo $^{7} \cdot$ Pirkko Pussinen $^{8} \cdot$ Tuomas Rauramaa $^{9} \cdot$ Juhana Frösen $^{3,7,10}$
}

Received: 24 November 2019 / Revised: 12 January 2020 / Accepted: 27 January 2020 / Published online: 7 February 2020

(C) The Author(s) 2020

\begin{abstract}
Degeneration of intracranial aneurysm wall is under active research and recent studies indicate an increased risk of rupture of intracranial aneurysm among patients with periodontal diseases. In addition, oral bacterial DNA has been identified from wall samples of ruptured and unruptured aneurysms. These novel findings led us to evaluate if oral diseases could predispose to pathological changes seen on intracranial aneurysm walls eventually leading to subarachnoid hemorrhage. The aim of this review is to consider mechanisms on the relationship between periodontitis and aneurysm rupture, focusing on recent evidence.
\end{abstract}

Keywords Intracranial aneurysm $\cdot$ Periodontitis $\cdot$ Pathogens $\cdot$ Oral diseases $\cdot$ Subarachnoidal hemorrhage

\section{Introduction}

Recently, our group found the association with periodontitis, formation of intracranial aneurysms (IA), and the risk of aneurysmal subarachnoid hemorrhage (aSAH) [25]. Together with the prior reports that DNA of oral bacteria is found in the wall of many ruptured intracranial aneurysms [64, 65], these results raised the intriguing question whether periodontitis and oral bacteria participate to the formation of IAs and to their progression towards rupture. We review the current research about the association of oral infections with aneurysms and other vascular diseases, and discuss the potential mechanisms by which oral infections may modulate, contribute to, or even cause the degenerative remodeling of the aneurysm

Joona Hallikainen

joona.hallikainen@kuh.fi

Institute of Dentistry, University of Eastern Finland, Kuopio, Finland

2 Department of Oral and Maxillofacial Diseases, Kuopio University Hospital, Puijonlaaksontie 2, 70210 Kuopio, Finland

3 Hemorrhagic Brain Pathology Research Group, Kuopio University Hospital, Kuopio, Finland

4 Department of Biomedicine, University of Eastern Finland, Kuopio, Finland

5 Public Health Evaluation and Projection Unit, National Institute for Health and Welfare, Helsinki, Finland wall and as such predispose to the risk of aneurysmal subarachnoid hemorrhage.

\section{Intracranial aneurysms as a clinical challenge-need for identification of rupture-prone aneurysms}

Intracranial aneurysms (IA) are pathological dilatations of cerebral arteries, most often saccular in shape and frequently found in proximal cerebral artery bifurcations [30]. Aneurysms are relatively common with a prevalence of 2 $3 \%$ in the general population $[70,91]$.

Although unruptured IAs are common, intracranial hemorrhage caused by IA rupture is a quite rare event affecting 10-11/ 100000 population per year in Western populations [32]. In fact,

6 Medical Research Center, Oulu University Hospital and University of Oulu, Oulu, Finland

7 Hemorrhagic Brain Pathology Research Group, Tampere University Hospital and University of Tampere, Tampere, Finland

8 Oral and Maxillofacial Diseases, University of Helsinki and Helsinki University Hospital, Helsinki, Finland

9 Department of Pathology, Kuopio University Hospital and University of Eastern Finland, Kuopio, Finland

10 Department of Neurosurgery, Tampere University Hospital and University of Tampere, Tampere, Finland 
based on epidemiological data, it seems that only approximately $1 \%$ of IAs rupture per year [70] and many of them actually never rupture during the lifetime of the person carrying them [41]. However, because of the serious consequences that IA rupture and subsequent intracranial hemorrhage have (40\% mortality and most of the survivors being left with significant neurological impairment $[54,78]$ ), many of the diagnosed unruptured IAs are treated to prevent rupture. Preventive treatment is done by endovascular embolization of aneurysm sack or by microsurgical ligation of the aneurysm neck, both of which exclude the aneurysm from systemic circulation. Both of the current treatment options are associated with significant risk of serious neurological complications (5-7\%), including mortality (1-2\%) $[43,53]$. Therefore, it is paramount to focus intervention only to those IAs at risk of rupture. This remains a challenge.

The discrepancy between the relatively high prevalence of unruptured IAs and the low incidence of IA rupture, together with the observation that only $1 / 3$ of unruptured IAs ruptured during a life-long follow-up [41], strongly suggests that IA formation and IA rupture are two separate phenomena with different pathological background. Moreover, these observations suggest that while some IA walls are able to adapt to the mechanical load imposed on them, in others degenerative remodeling makes the IAs rupture-prone. This in turn implies that by pharmacological manipulation of the adaptive or degenerative remodeling of the IA wall, it might be possible to keep the formed unruptured IAs stable and prevent rupture. To achieve this, the pathophysiological mechanisms guiding IA growth and rupture, i.e., adaptive and degenerative wall remodeling, need to be understood. Moreover, biomarkers for an IA wall capable of adaptive remodeling are needed to identify those IAs that can be stabilized with drug therapy.

\section{Intracranial aneurysms show chronic inflammation that is associated with wall degeneration and rupture}

Since human tissue samples from the site of IA initiation are inherently difficult to obtain, most of our knowledge of the pathophysiological mechanisms leading to IA formation is derived from animal models of induced IA formation [1, 27, 34, 39]. Current understanding is that IAs form as the end result of flow-driven inflammatory cell-mediated cerebral artery wall remodeling at the sites where high flow causes high wall shear stress (WSS) [22, 75](Fig. 1). However, not all cerebral artery bifurcations exposed to high WSS develop IAs, suggesting that additional factors are needed [22]. A common feature to IA initiation is the disruption of internal elastic lamina (IEL) [27, 39], resulting in distension of the vessel wall to the extent that collagen fibers allow [22]. In a mouse model of induced IA formation, IEL disruption is related to flow-induced macrophage infiltration [22, 34]. In humans, however, systemic elastase activity may play a significant role since increased serum elastase concentrations associate with IAs [10], although the source is unknown. Potential sources for circulating elastase are macrophages or neutrophils $[13,68]$. Given that chewing or brushing teeth predisposes to transient bacteremia, especially in patients with gingivitis or periodontitis [16, 28, 49, 84], activation of circulating neutrophils as a response to transient bacteremia of periodontal pathogens with subsequent formation of neutrophil extracellular traps (NETs) and elastase release [13] could lead to wall degeneration (Fig. 2) - thus explaining why IA form for some but not all persons under high flow and shear stress towards bifurcations of cerebral arteries [75].

In humans, increased infiltration of leukocytes, mainly macrophages and to some extent T cells, is observed in ruptured IA walls compared with unruptured IA walls $[18,37,55]$. The observation that inflammatory cell infiltration is present in unruptured IAs as well as in ruptured IAs operated early after rupture, combined with the observation that this inflammatory cell infiltration does not associate with time from rupture [18], strongly implies that the inflammatory cell infiltration is present before rupture. Thus, inflammatory cell infiltration associates with wall degeneration in both unruptured and ruptured IA walls $[56,57]$. In animal models of induced IA formation, blocking macrophage infiltration or activation inhibits the formation, growth, and rupture of the IAs [2, 3, 36, 74].
Fig. 1 Circulating periodontal bacteria, their antibodies, circulating elastase and inflammatory reaction products causes endothelial dysfunction in arterial wall, which predisposes arterial wall to high flow condition. Simultaneously macrophage infiltration is observed in the arterial wall and IA formation accelerates

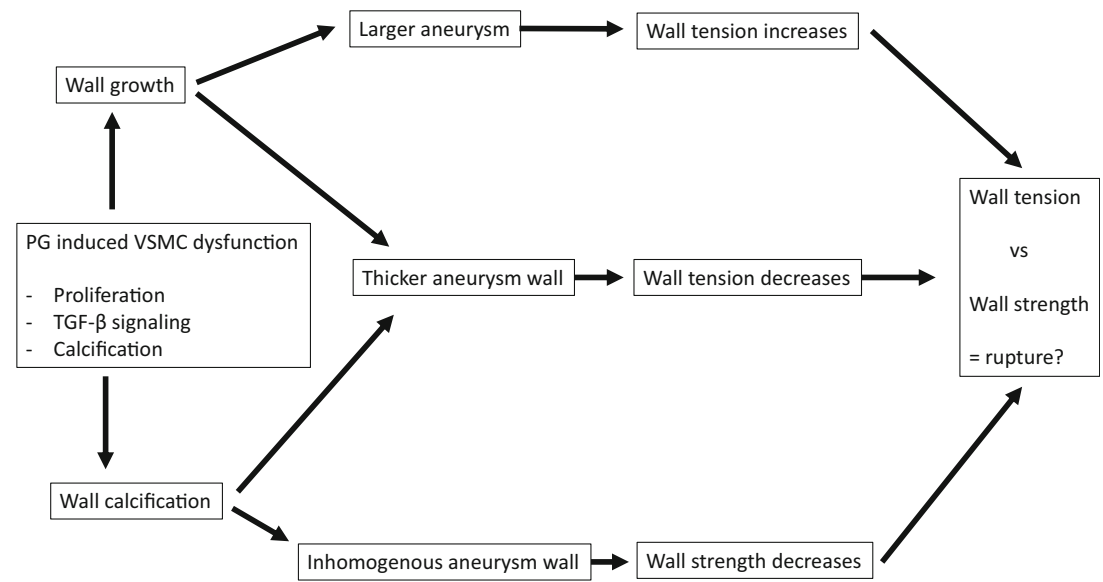


Fig. 2 Porphyromonas gingivalis (PG) activates circulating neutrophils and induces formation of neutrophil extracellular traps (NET) in cerebral arteries. Endured PG challenge leads to neutrophil-derived elastase overload and MPO production causing disruption of the internal elastic lamina (IEL) of the arterial wall and IA formation initiates

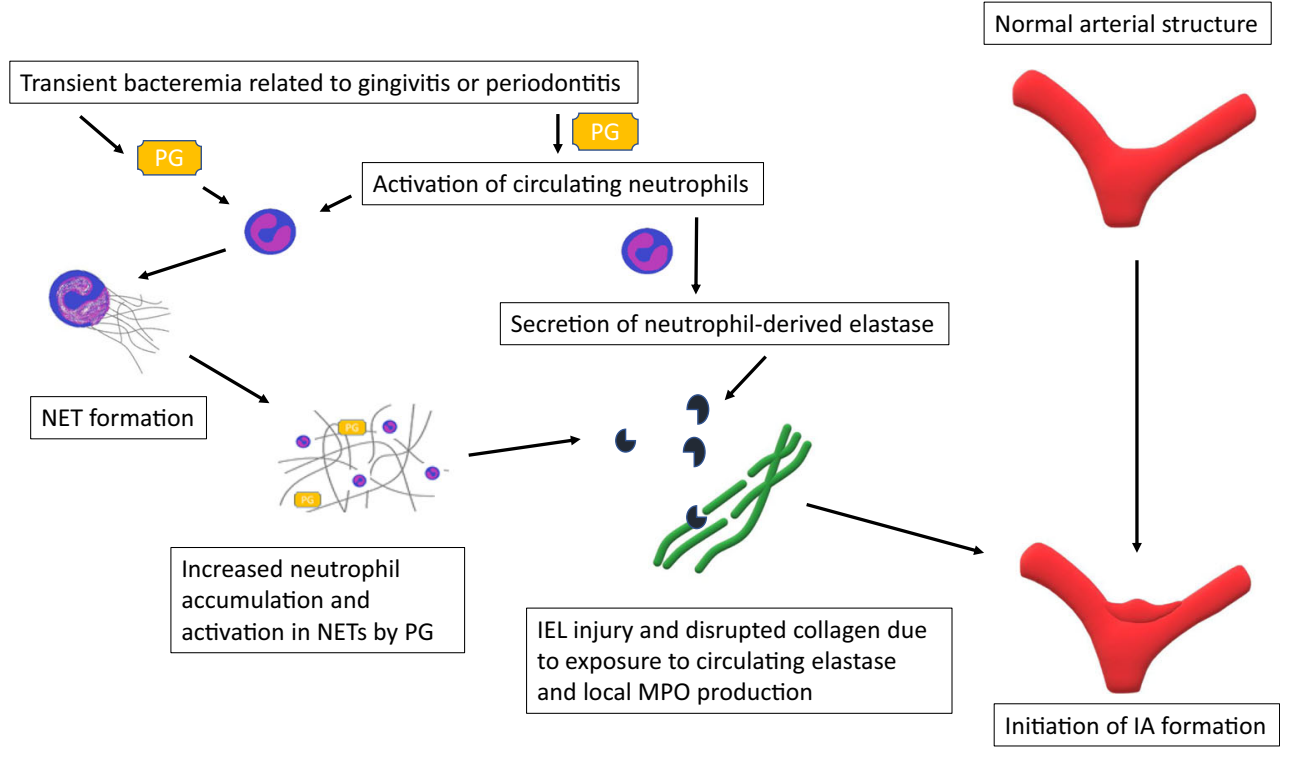

Inflammatory response mediated especially by macrophages is an essential part of the flow-induced vessel remodeling that leads to aneurysm initiation and growth [22]. However, in the human IA wall also a humoral immune response and activation of the complement system are observed and associating with wall degeneration in unruptured IA walls as well as with rupture $[86,87]$. This strongly implies that the chronic inflammation seen in human IA walls is not just related to flow-induced remodeling, especially since there is very high variation in the inflammation degree among IAs $[18,55$, 86] despite the fact that all are exposed to non-physiological flow. The cause of this inflammation in the IA wall is unclear. Potential triggers of inflammation include circulating lipids $[20,88]$ and periodontal and cariogenic bacteria $[31,64,65]$.

\section{The highly prevalent oral infections, dental caries and periodontitis, and their systemic effects}

Dental caries and periodontitis are both highly prevalent oral diseases worldwide despite the modern dental therapy and accumulating knowledge of oral diseases. Caries is an infective disease of hard tissues of the tooth, and the prevalence of untreated caries is one-third of the global population as well as in Europe [17] In the USA and Asia pacific, the prevalence varies between 22 and $25 \%$ [17]. Another common oral disease, periodontitis, is also to a large extent preventable inflammatory disease and highly underdiagnosed. Its severe form affects about $10 \%$ of the global population, and $7 \%$ in Asia pacific area [17]. In the USA, the prevalence of mild to moderate and severe periodontitis is reported to be $46 \%$ and $9 \%$ of adults, respectively [14]. In Europe, corresponding prevalence is $40-60 \%$ and $10-20 \%$ [17], respectively.

The microbial load on tooth surface, dental plaque, composed of hundreds of microbial species [59]. Periodontal pathogenesis initiates by microbial accumulation on the tooth surface resulting a reversible gingival inflammation known as gingivitis [77, 83], which may progress to periodontitis among susceptible individuals when the normally dominating beneficial species become lessened and replaced by pathogenic species [40]. Therefore, endured microbial burden, in form of dental plaque or calculus, leads to a chronic inflammatory disease - periodontitis. Without interventional therapy, periodontitis leads to breakdown of both soft and hard tissue mainly via inflammatory host response [11] causing loss of tooth attachment and eventually loss of alveolar bone in the jaws. Periodontitis not only degenerates tooth surrounding structures but affects the inflammatory system $[35,51$, $52,60,62]$ and systemic health [12, 25, 38, 45, 46, 63, 79].

Periodontitis is associated with the risk of several diseases. For example, in rheumatoid arthritis, Porphyromonas gingivalis (PG), one of the most common periodontal pathogens, seems to be potential generator of autoantibodies [50]. Periodontitis has also been associated with atherosclerosis, stroke [38, 46, 63], and abdominal aortic aneurysms (AAA) [12, 45, 79]. Very recently, our group showed that periodontitis or gingivitis associate also with aSAH and IA formation [25]. In addition to this, another recent study reported an association between aSAH and being a carriage of specific strains of Streptococcus mutans, a significant contributor to tooth decay [31]. These clinical studies suggest that oral infections and exposure to oral pathogens associate with risk of IA formation and aSAH.

\section{Potential role of periodontal pathogens in the pathobiology of the intracranial aneurysm}

In addition to the clinical association of periodontitis with IA formation and aSAH suggesting a potential causative association, a recent experimental study has reported that temporary ablation of the gut microbiome prevents IA formation through indirect 
modulation of the inflammatory remodeling in the cerebral arteries $[21,73]$. This experimental study highlights the thus far unnoticed importance of microbial exposure in the pathogenesis of IAs.

While it has been long known that septic, bacterial emboli ending up in cerebral arteries may cause formation of socalled mycotic aneurysms through focal inflammation of the artery wall, most saccular IAs have been considered as being aseptic. However, a landmark study screening human IA wall tissue samples for the presence of any bacterial DNA demonstrated DNA of oral pathogens in up to $50 \%$ of ruptured IA walls $[64,65]$. The fact that the remaining $50 \%$ were negative for any bacterial DNA demonstrates that IAs can form without direct bacterial involvement. The combination of having an epidemiological association between periodontal infection and IA formation and rupture [25,66], experimental proof that microbiome exposure modulates IA formation [21, 73], and that even presence of oral pathogen remnants is found in many IA walls $[64,65]$ justifies the hypothesis that periodontal pathogens contribute to the risk of IA formation and rupture through indirect or direct modulation of the inflammatory remodeling in the cerebral artery and IA wall.

\section{Potential mechanisms through which oral pathogens can affect inflammatory remodeling in the IA wall}

We will focus on those periodontal pathogens that have been identified in walls of ruptured intracranial aneurysms by Pyysalo et al. $[64,65]$ and discuss through their known role in other vascular diseases their potential contribution to IA pathogenesis.

The importance of macrophage infiltration for the inflammatory remodeling leading to IA formation has been demonstrated by several studies $[3,22,36,74,80]$, including the landmark experimental studies by Kanematsu et al., Shimada et al., and Aoki et al. [3, 36, 74]. P. gingivalis can stay viable in human macrophages and dendritic cells [7, 76, 92] and thus possibly disseminate to IA wall via macrophage infiltration. P. gingivalis seems to be capable of modifying the function of dendritic cells, for example, the secretion of collagen degrading MMP-9 is promoted in dendritic cells that are infected with $P$. gingivalis [7]. In addition, presence of $P$. gingivalis and Fusobacterium nucleatum (FN) DNA has shown to induce proinflammatory cytokine production in macrophages [71, 72]. Thus $P$. gingivalis infection of the macrophages that infiltrate the cerebral arteries would likely lead to excessive collagen degradation and local inflammation response, predisposing to IA formation.

Another mechanism through which circulating components of oral bacteria could enhance or amplify the inflammatory remodeling of the cerebral artery wall is through activation of toll-like receptors by LPS, e.g., from $P$. gingivalis in luminal thrombus [12](Fig. 3). Toll-like receptors are expressed in aneurysm walls [64] and their stimulation triggers activation of the transcription factor NFkB [3], a main mediator of the inflammatory remodeling leading to IA formation [3]. As a result, having oral bacteria-derived components in the circulation would promote inflammatory vessel remodeling triggered by, e.g., high flow, and thus predispose to IA formation.

Viable periodontal bacteria, namely $P$. gingivalis, Aggregatibacter actinomycetemcomitans (AA), and Treponema denticola (TD), have been found in human atheromas $[8,44,67]$ (Fig. 4). In vitro and in vivo studies have well established that it is biologically plausible that periodontitis accelerates atherosclerosis $[6,33,48,69]$. Recent mechanistic study using $A p o E^{\text {null }}$ mouse model revealed an ability of $P$. gingivalis to actively invade luminal side of aortic wall, retaining its vitality and leading to greater aortic plaque area $[47,90]$. In another mechanistic study using a pig model, circulating $P$. gingivalis promoted atherosclerosis not only in hypercholesterolemic pigs but also normocholesterolemic ones [6]. These findings suggest that the active invasion of periodontal pathogens in the artery wall with or without presence of cholesterol can be a potential trigger of atherosclerotic activity. Nearly all intracranial aneurysms feature at least minor atherosclerotic changes and advanced atherosclerotic changes are seen in large numbers [20,42]. Of note is that the accumulation of lipid and oxidized low-density lipoprotein (oxLDL) was found to associate with IA wall degeneration, loss of mural cells, and also IA rupture, despite normal lipid levels [20]. Interestingly, not only has $P$. gingivalis been shown to accelerate atherosclerosis $[6,90]$ but immunization against it has been shown to reduce atherosclerotic changes $[24,89]$. Thus, accumulation of oxidized lipids to the IA wall and subsequent atherosclerotic remodeling might be altered indirectly by systemic immunization induced by local periodontitis. It seems possible that the presence of $P$. gingivalis in the IA wall or immune response induced by $P$. gingivalis elsewhere in the body may modulate directly or indirectly the progression of atherosclerotic changes and lipid-induced inflammation in the IA wall.

Periodontitis is common also among patients with abdominal aortic aneurysms (AAA) and periodontal bacterial DNA have been identified in AAA wall structure as well as in the thrombus lining the AAA inner wall $[12,45]$. Presence of periodontal bacteria promotes AAA growth, i.e., enlargement of luminal diameter $[4,12]$, and thus could predispose AAA to rupture. $P$. gingivalis appears to promote AAA pathogenesis by maintaining inflammation and increasing oxidative stress in the AAA wall via adhesion to the intraluminal thrombus [12]. P. gingivalis has an affinity for thrombus and can passively accumulate to sites of thrombosis if it is present in the bloodstream [12]. In the thrombus, $P$. gingivalis is capable of inducing the formation of neutrophil-derived extracellular traps (NETs), which increases further the accumulation of neutrophils to the thrombus [12]. Fontaine et al. have shown that the neutrophils in the intraluminal thrombus are a major source of proteolytic activity as they release matrix metalloproteinases MMP-8, MMP-9, and elastase [15, 29]. Furthermore, the neutrophils attracted to luminal thrombus produce proteases and cytotoxic enzymes such as 


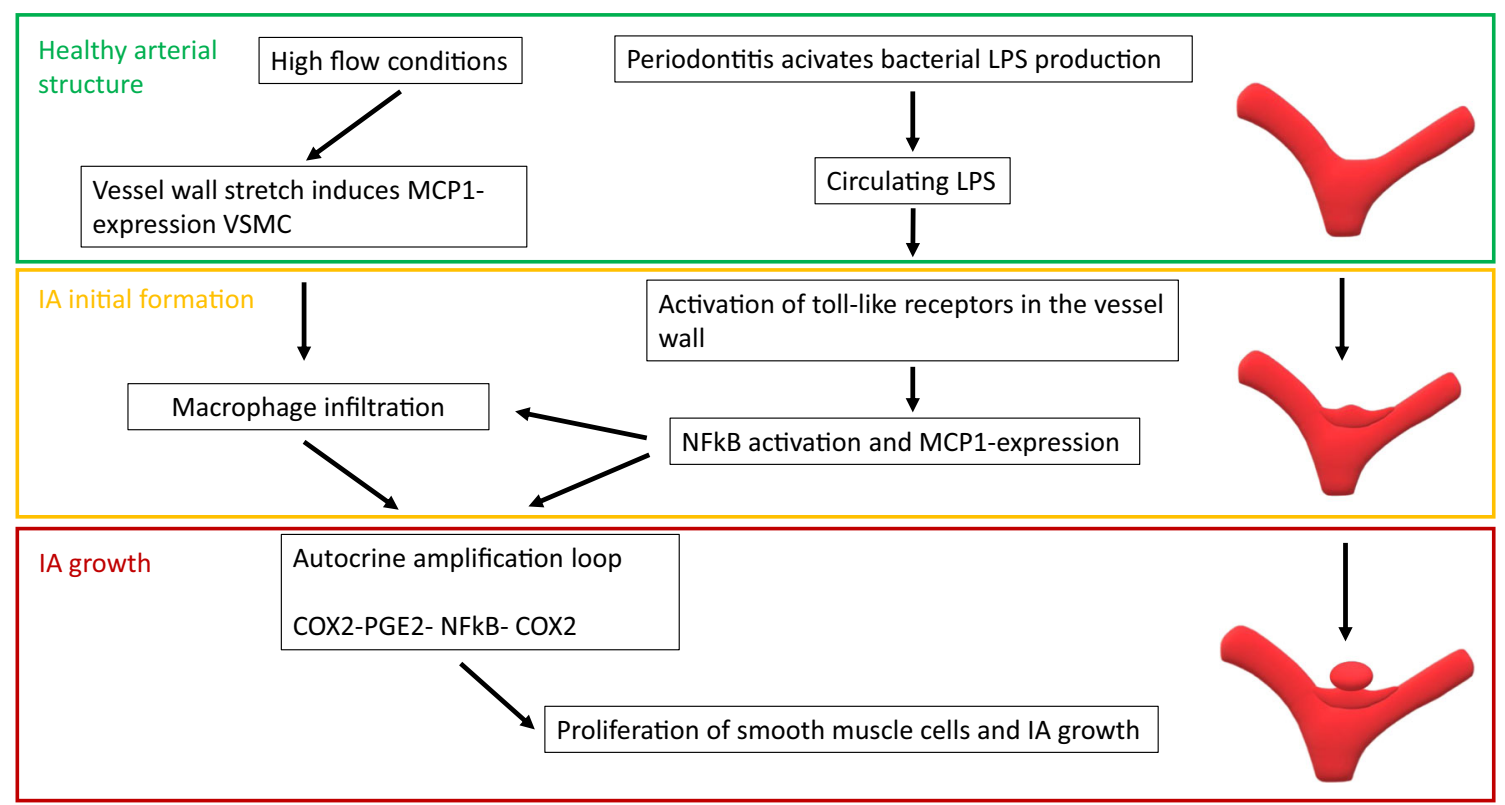

Fig. 3 High flow conditions stretch the vessel wall and induce monocyte chemoattractant protein 1 (MCP-1) in vascular smooth muscle cells (VSMC) attracting invading macrophages to vessel wall. Similar MCP1 production is caused by lipopolysaccharide (LPS) production of periodontal bacteria via activating nuclear factor $\mathrm{kB}$ (NFkB) -signaling via

myeloperoxidase (MPO) [15, 29], which generates, e.g., hydrogen peroxide and hypoclorous acid intended to kill bacteria and leading to very high oxidative stress locally [26]. In addition to increasing the local recruitment of neutrophils, $P$. gingivalis can also activate the neutrophils in the thrombus, thus accelerating the neutrophil-derived proteolytic and cytotoxic injury [12](Fig. toll-like receptors. These mechanisms lead to cyclo-oxygenase 2-prostaglandin E2-NFkB-cyclo-oxygenase 2 (COX2-PGE2-NFkB-COX2)-amplifying loop in IA wall and lead to proliferation of smooth muscle cells expanding the IA

2). This cytotoxic injury is in part mediated by MPO. In summary, presence of $P$. gingivalis in the intraluminal thrombus or adjacent AAA wall can trigger or enhance the activation and recruitment of neutrophils, leading to excessive proteolytic and cytotoxic injury to the vessel wall. Similarly to AAAs, neutrophils are recruited to the luminal thrombus lining the IA walls

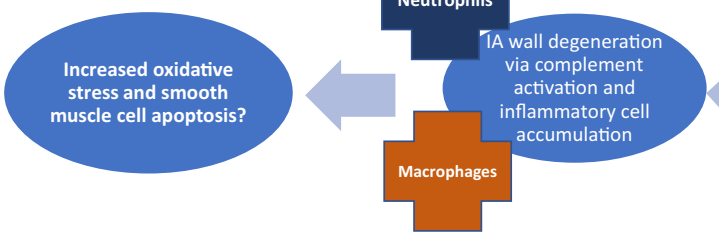

Fig. 4 Periodontal bacteria have ability to dysregulate complement activity with their proteinase production (Porphyromonas gingivalis PG, Prevotella intermedia PI, and Tannerella forsythia TF) or directly binding complement factor $\mathrm{C} 4 \mathrm{bp}$ and factor $\mathrm{H}$ (Porphyromonas gingivalis PG, Prevotella intermedia PI, Treponema denticola TD, and

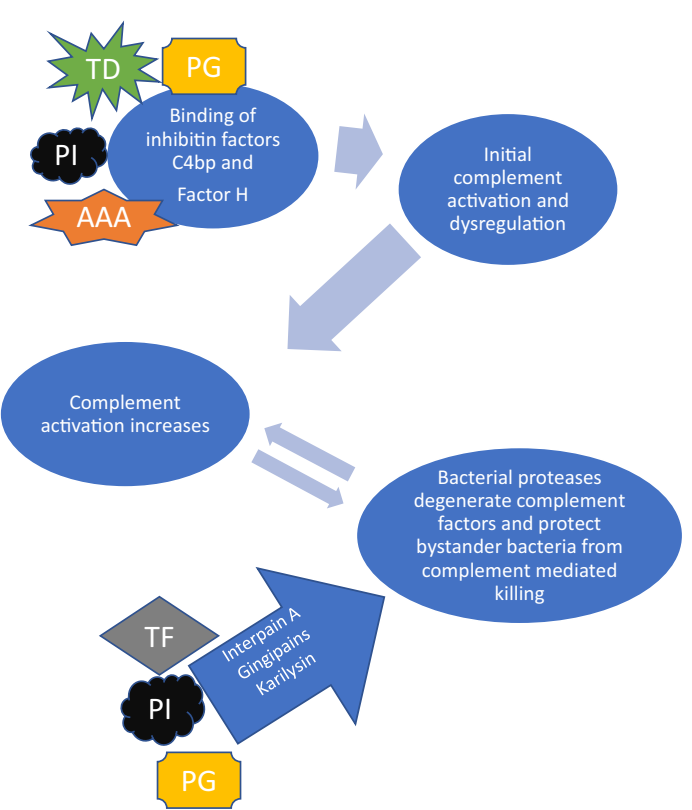

Aggregatibacter actinomycetemcomitans AAA). These bacteria simultaneously accelerate complement activity yet evade complementmediated killing is unique and could partially explain inflammation in IA wall, especially since oral bacterial DNA is found in unruptured and ruptured IA walls 
$[18,19,56]$. Luminal thrombus is common in IAs [18], as is periodontitis in IA patients $[25,66]$ suggesting that $P$. gingivalis might accelerate neutrophil-driven thrombus-derived proteolytic and cytotoxic injury in the IA wall similarly to the AAA walls. Indeed, MPO expression has been demonstrated in human IA walls $[23,56]$ and locally higher MPO concentrations have been observed in serum from aneurysm sac than to femoral artery blood [9].

Besides the infiltration of inflammatory cells such as macrophages and neutrophils, activation of the complement system is involved in IA wall degeneration and rupture [86, 87]. It has been shown earlier that periodontal bacteria can dysregulate complement activity in vitro by binding to or degenerating complement factors [35, 51, 52, 60, 62]. Of periodontal pathogens, specific strains of Prevotella intermedia (PI) and $P$. gingivalis participate in complement activation by binding factor $\mathrm{H}$ [51] and C4bp respectively [61]. Treponema denticola (TD) and A. actinomycetemcomitans, common periodontal pathogens, have ability to bind factor $\mathrm{H}[5,52]$. These bacteria do not only dysregulate complement activity but also evade complement-mediated killing in response of binding factor $\mathrm{H}$ $[51,52]$. It is noteworthy that DNA of both P. intermedia and T. denticola have been identified in some of ruptured IAs [64, 65]. Interestingly, P. gingivalis, P. intermedia, and Tannerella forsythia (TF) are capable of evading complement-mediated killing by altering complement activity and degenerating complement factors via their bacterial proteases, while protecting other bystander-bacteria $[35,60,62]$. This ability of periodontal bacteria to activate complement while evading complementmediated killing may in part explain the complement activation seen in the IA wall in association with IA wall degeneration.

In addition to the mechanisms described above, periodontal bacteria may also trigger IA wall degeneration via endothelial dysfunction, which seems to be one of the key events that triggers the lipid accumulation, luminal thrombosis, and inflammation that associate with the IA wall degeneration [19]. A recent meta-analysis concluded that periodontal bacteria predispose to endothelial dysfunction [58]. Moreover, endothelial dysfunction improves with periodontal treatment $[58,85]$. Endothelial dysfunction can be at least in part caused by bacterial burden of periodontitis and furthermore, endothelial dysfunction could explain why periodontal bacteria are often found in the sites of vascular diseases, e.g., IA walls and atheromas. Interestingly, periodontitis patients also have higher concentration of circulating oxidized LDL particles in the blood [81, 82], another mechanism more through which periodontitis can accelerate local atherosclerotic remodeling in the IA wall.

\section{Conclusion}

Although the association of aneurysm rupture with chronic inflammation of the aneurysm wall is well established, the triggers for this inflammatory reaction are incompletely understood. The recent finding that periodontitis or gingivitis associates with increased risk of aSAH together with DNA of oral bacteria found in the walls of many IAs raises the hypothesis that oral infections are related to the inflammation of the IA wall. In this review, we presented several mechanisms by which periodontitis and periodontal pathogens can contribute to the degenerative remodeling of the IA wall. These mechanisms merit further investigation and may reveal a previously unknown and treatable risk factor for the deadly aneurysmal subarachnoid hemorrhage.

Funding Information Open access funding provided by University of Eastern Finland (UEF) including Kuopio University Hospital.

\section{Compliance with ethical standards}

Conflict of interest The authors declare that they have no conflict of interest.

Ethical approval This article does not contain any studies with human participants or animals performed by any of the authors.

Open Access This article is licensed under a Creative Commons Attribution 4.0 International License, which permits use, sharing, adaptation, distribution and reproduction in any medium or format, as long as you give appropriate credit to the original author(s) and the source, provide a link to the Creative Commons licence, and indicate if changes were made. The images or other third party material in this article are included in the article's Creative Commons licence, unless indicated otherwise in a credit line to the material. If material is not included in the article's Creative Commons licence and your intended use is not permitted by statutory regulation or exceeds the permitted use, you will need to obtain permission directly from the copyright holder. To view a copy of this licence, visit http://creativecommons.org/licenses/by/4.0/.

\section{References}

1. Aoki T, Nishimura M (2011, 2011: 535921) The development and the use of experimental animal models to study the underlying mechanisms of CA formation. J Biomed Biotechnol. https://doi. org $/ 10.1155 / 2011 / 535921$

2. Aoki T, Kataoka H, Ishibashi R, Nozaki K, Egashira K, Hashimoto $\mathrm{N}$ (2009) Impact of monocyte chemoattractant protein-1 deficiency on cerebral aneurysm formation. Stroke 40:942-951. https://doi. org/10.1161/STROKEAHA.108.532556

3. Aoki T, Frosen J, Fukuda M, Bando K, Shioi G, Tsuji K, Ollikainen E, Nozaki K, Laakkonen J, Narumiya S (2017) Prostaglandin E2EP2-NF-kappaB signaling in macrophages as a potential therapeutic target for intracranial aneurysms. Sci Signal 10. https://doi.org/ 10.1126/scisignal.aah6037

4. Aoyama N, Suzuki J, Wang D, Ogawa M, Kobayashi N, Hanatani T, Takeuchi Y, Izumi Y, Isobe M (2011) Porphyromonas gingivalis promotes murine abdominal aortic aneurysms via matrix metalloproteinase-2 induction. J Periodontal Res 46:176-183. https://doi.org/10.1111/j.1600-0765.2010.01326.x

5. Asakawa R, Komatsuzawa H, Kawai T, Yamada S, Goncalves RB, Izumi S, Fujiwara T, Nakano Y, Suzuki N, Uchida Y, Ouhara K, 
Shiba H, Taubman MA, Kurihara H, Sugai M (2003) Outer membrane protein 100, a versatile virulence factor of Actinobacillus actinomycetemcomitans. Mol Microbiol 50:1125-1139

6. Brodala N, Merricks EP, Bellinger DA, Damrongsri D, Offenbacher S, Beck J, Madianos P, Sotres D, Chang YL, Koch G, Nichols TC (2005) Porphyromonas gingivalis bacteremia induces coronary and aortic atherosclerosis in normocholesterolemic and hypercholesterolemic pigs. Arterioscler Thromb Vasc Biol 25:1446-1451. https:// doi.org/10.1161/01.ATV.0000167525.69400.9c

7. Carrion J, Scisci E, Miles B, Sabino GJ, Zeituni AE, Gu Y, Bear A, Genco CA, Brown DL, Cutler CW (2012) Microbial carriage state of peripheral blood dendritic cells (DCs) in chronic periodontitis influences DC differentiation, atherogenic potential. J Immunol 189:3178-3187. https://doi.org/10.4049/jimmunol.1201053

8. Cavrini F, Sambri V, Moter A, Servidio D, Marangoni A, Montebugnoli L, Foschi F, Prati C, Di Bartolomeo R, Cevenini R (2005) Molecular detection of Treponema denticola and Porphyromonas gingivalis in carotid and aortic atheromatous plaques by FISH: report of two cases. J Med Microbiol 54:93-96. https://doi.org/10.1099/jmm.0.45845-0

9. Chu Y, Wilson K, Gu H, Wegman-Points L, Dooley SA, Pierce GL, Cheng G, Pena Silva RA, Heistad DD, Hasan D (2015) Myeloperoxidase is increased in human cerebral aneurysms and increases formation and rupture of cerebral aneurysms in mice. Stroke 46:1651-1656. https://doi.org/10.1161/STROKEAHA.114.008589

10. Connolly ES Jr, Fiore AJ, Winfree CJ, Prestigiacoma CJ, Goldman JE, Solomon RA (1997) Elastin degradation in the superficial temporal arteries of patients with intracranial aneurysms reflects changes in plasma elastase. Neurosurgery 40:903-909. https://doi.org/10. 1097/00006123-199705000-00003

11. Darveau RP (2010) Periodontitis: a polymicrobial disruption of host homeostasis. Nat Rev Microbiol 8:481-490. https://doi.org/10. 1038/nrmicro2337

12. Delbosc S, Alsac JM, Journe C, Louedec L, Castier Y, BonnaureMallet M, Ruimy R, Rossignol P, Bouchard P, Michel JB, Meilhac $\mathrm{O}$ (2011) Porphyromonas gingivalis participates in pathogenesis of human abdominal aortic aneurysm by neutrophil activation. Proof of concept in rats. PLoS One 6:e18679. https://doi.org/10.1371/ journal.pone.0018679

13. Delgado-Rizo V, Martinez-Guzman MA, Iniguez-Gutierrez L, Garcia-Orozco A, Alvarado-Navarro A, Fafutis-Morris M (2017) Neutrophil extracellular traps and its implications in inflammation: an overview. Front Immunol 8:81. https://doi.org/10.3389/fimmu. 2017.00081

14. Eke PI, Dye BA, Wei L, Slade GD, Thornton-Evans GO, Borgnakke WS, Taylor GW, Page RC, Beck JD, Genco RJ (2015) Update on prevalence of periodontitis in adults in the United States: NHANES 2009 to 2012. J Periodontol 86:611622. https://doi.org/10.1902/jop.2015.140520

15. Fontaine V, Jacob MP, Houard X, Rossignol P, Plissonnier D, Angles-Cano E, Michel JB (2002) Involvement of the mural thrombus as a site of protease release and activation in human aortic aneurysms. Am J Pathol 161:1701-1710

16. Forner L, Larsen T, Kilian M, Holmstrup P (2006) Incidence of bacteremia after chewing, tooth brushing and scaling in individuals with periodontal inflammation. J Clin Periodontol 33:401-407

17. Frencken JE, Sharma P, Stenhouse L, Green D, Laverty D, Dietrich $\mathrm{T}$ (2017) Global epidemiology of dental caries and severe periodontitis - a comprehensive review. J Clin Periodontol 44(Suppl 18): S94-S105. https://doi.org/10.1111/jcpe.12677

18. Frosen J, Piippo A, Paetau A, Kangasniemi M, Niemela M, Hernesniemi J, Jaaskelainen J (2004) Remodeling of saccular cerebral artery aneurysm wall is associated with rupture: histological analysis of 24 unruptured and 42 ruptured cases. Stroke 35:22872293. https://doi.org/10.1161/01.STR.0000140636.30204.da
19. Frosen J, Tulamo R, Paetau A, Laaksamo E, Korja M, Laakso A, Niemela M, Hernesniemi J (2012) Saccular intracranial aneurysm: pathology and mechanisms. Acta Neuropathol 123:773-786. https://doi.org/10.1007/s00401-011-0939-3

20. Frosen J, Tulamo R, Heikura T, Sammalkorpi S, Niemela M, Hernesniemi J, Levonen AL, Horkko S, Yla-Herttuala S (2013) Lipid accumulation, lipid oxidation, and low plasma levels of acquired antibodies against oxidized lipids associate with degeneration and rupture of the intracranial aneurysm wall. Acta Neuropathol Commun 1:71. https://doi.org/10.1186/2051-5960-1-71

21. Frosen J, Hallikainen J, Pyysalo M, Koivisto T, Lindgren A (2019) Letter by Frosen et al regarding article "potential influences of gut microbiota on the formation of intracranial aneurysm". Hypertension 74:e22-e23. https://doi.org/10.1161/ HYPERTENSIONAHA.119.13253

22. Frösen J, Cebral J, Robertson AM, Aoki T Flow induced inflammation mediated artery wall remodeling in the formation and progression of intracranial aneurysms. Neurosurg Focus

23. Gounis MJ, Vedantham S, Weaver JP, Puri AS, Brooks CS, Wakhloo AK, Bogdanov AA Jr (2014) Myeloperoxidase in human intracranial aneurysms: preliminary evidence. Stroke 45:1474 1477. https://doi.org/10.1161/STROKEAHA.114.004956

24. Hagiwara M, Kurita-Ochiai T, Kobayashi R, Hashizume-Takizawa T, Yamazaki K, Yamamoto M (2014) Sublingual vaccine with GroEL attenuates atherosclerosis. J Dent Res 93:382-387. https:// doi.org/10.1177/0022034514523784

25. Hallikainen J, Lindgren A, Savolainen J, Selander T, Jula A, Narhi M, Koivisto T, Kellokoski J, Ylostalo P, Suominen AL, Frosen J (2019) Periodontitis and gingival bleeding associate with intracranial aneurysms and risk of aneurysmal subarachnoid hemorrhage. Neurosurg Rev. https://doi.org/10.1007/s10143-019-01097-1

26. Hampton MB, Kettle AJ, Winterbourn CC (1998) Inside the neutrophil phagosome: oxidants, myeloperoxidase, and bacterial killing. Blood 92:3007-3017

27. Hazama F, Hashimoto N (1987) An animal model of cerebral aneurysms. Neuropathol Appl Neurobiol 13:77-90

28. Horliana AC, Chambrone L, Foz AM, Artese HP, Rabelo Mde S, Pannuti CM, Romito GA (2014) Dissemination of periodontal pathogens in the bloodstream after periodontal procedures: a systematic review. PLoS One 9:e98271. https://doi.org/10.1371/journal.pone. 0098271

29. Houard X, Ollivier V, Louedec L, Michel JB, Back M (2009) Differential inflammatory activity across human abdominal aortic aneurysms reveals neutrophil-derived leukotriene B4 as a major chemotactic factor released from the intraluminal thrombus. FASEB J 23:1376-1383. https://doi.org/10.1096/fj.08-116202

30. Huttunen T, von und zu Fraunberg M, Frosen J, Lehecka M, Tromp G, Helin K, Koivisto T, Rinne J, Ronkainen A, Hernesniemi J, Jaaskelainen JE (2010) Saccular intracranial aneurysm disease: distribution of site, size, and age suggests different etiologies for aneurysm formation and rupture in 316 familial and 1454 sporadic eastern Finnish patients. Neurosurgery 66:631-638; discussion 638. https://doi.org/10.1227/01.NEU.0000367634.89384.4B

31. Inenaga C, Hokamura K, Nakano K, Nomura R, Naka S, Ohashi T, Ooshima T, Kuriyama N, Hamasaki T, Wada K, Umemura K, Tanaka T (2018) A potential new risk factor for stroke: Streptococcus mutans with collagen-binding protein. World Neurosurg 113:e77-e81

32. Ingall T, Asplund K, Mahonen M, Bonita R (2000) A multinational comparison of subarachnoid hemorrhage epidemiology in the WHO MONICA stroke study. Stroke 31:1054-1061

33. Jain A, Batista EL Jr, Serhan C, Stahl GL, Van Dyke TE (2003) Role for periodontitis in the progression of lipid deposition in an animal model. Infect Immun 71:6012-6018

34. Jamous MA, Nagahiro S, Kitazato KT, Tamura T, Aziz HA, Shono M, Satoh K (2007) Endothelial injury and inflammatory response 
induced by hemodynamic changes preceding intracranial aneurysm formation: experimental study in rats. J Neurosurg 107:405-411. https://doi.org/10.3171/JNS-07/08/0405

35. Jusko M, Potempa J, Karim AY, Ksiazek M, Riesbeck K, Garred P, Eick S, Blom AM (2012) A metalloproteinase karilysin present in the majority of Tannerella forsythia isolates inhibits all pathways of the complement system. J Immunol 188:2338-2349. https:/doi. org/10.4049/jimmunol.1101240

36. Kanematsu Y, Kanematsu M, Kurihara C, Tada Y, Tsou TL, van Rooijen N, Lawton MT, Young WL, Liang EI, Nuki Y, Hashimoto $\mathrm{T}$ (2011) Critical roles of macrophages in the formation of intracranial aneurysm. Stroke 42:173-178. https://doi.org/10.1161/ STROKEAHA.110.590976

37. Kataoka K, Taneda M, Asai T, Kinoshita A, Ito M, Kuroda R (1999) Structural fragility and inflammatory response of ruptured cerebral aneurysms. A comparative study between ruptured and unruptured cerebral aneurysms. Stroke 30:1396-1401

38. Kebschull M, Demmer RT, Papapanou PN (2010) "Gum bug, leave my heart alone!"-epidemiologic and mechanistic evidence linking periodontal infections and atherosclerosis. J Dent Res 89:879-902. https://doi.org/10.1177/0022034510375281

39. Kim C, Cervos-Navarro J, Kikuchi H, Hashimoto N, Hazama F (1993) Degenerative changes in the internal elastic lamina relating to the development of saccular cerebral aneurysms in rats. Acta Neurochir 121:76-81

40. Kinane DF, Stathopoulou PG, Papapanou PN (2017) Periodontal diseases. Nat Rev Dis Primers 3:17038. https://doi.org/10.1038/ nrdp. 2017.38

41. Korja M, Lehto H, Juvela S (2014) Lifelong rupture risk of intracranial aneurysms depends on risk factors: a prospective Finnish cohort study. Stroke 45:1958-1963. https://doi.org/10.1161/ STROKEAHA.114.005318

42. Kosierkiewicz TA, Factor SM, Dickson DW (1994) Immunocytochemical studies of atherosclerotic lesions of cerebral berry aneurysms. J Neuropathol Exp Neurol 53:399-406

43. Kotowski M, Naggara O, Darsaut TE, Nolet S, Gevry G, Kouznetsov E, Raymond J (2013) Safety and occlusion rates of surgical treatment of unruptured intracranial aneurysms: a systematic review and meta-analysis of the literature from 1990 to 2011. J Neurol Neurosurg Psychiatry 84:42-48. https://doi.org/10.1136/ jnnp-2011-302068

44. Kozarov EV, Dorn BR, Shelburne CE, Dunn WA Jr, Progulske-Fox A (2005) Human atherosclerotic plaque contains viable invasive Actinobacillus actinomycetemcomitans and Porphyromonas gingivalis. Arterioscler Thromb Vasc Biol 25:17. https://doi.org/ 10.1161/01.ATV.0000155018.67835.1a

45. Kurihara N, Inoue Y, Iwai T, Umeda M, Huang Y, Ishikawa I (2004) Detection and localization of periodontopathic bacteria in abdominal aortic aneurysms. Eur J Vasc Endovasc Surg 28:553-558

46. Lafon A, Pereira B, Dufour T, Rigouby V, Giroud M, Bejot Y, Tubert-Jeannin S (2014) Periodontal disease and stroke: a metaanalysis of cohort studies. Eur J Neurol 21:1155-1157. https://doi. org/10.1111/ene. 12415

47. Lalla E, Lamster IB, Hofmann MA, Bucciarelli L, Jerud AP, Tucker S, Lu Y, Papapanou PN, Schmidt AM (2003) Oral infection with a periodontal pathogen accelerates early atherosclerosis in apolipoprotein E-null mice. Arterioscler Thromb Vasc Biol 23:1405-1411. https://doi.org/10.1161/01.ATV.0000082462.26258.FE

48. Li L, Messas E, Batista EL Jr, Levine RA, Amar S (2002) Porphyromonas gingivalis infection accelerates the progression of atherosclerosis in a heterozygous apolipoprotein E-deficient murine model. Circulation 105:861-867

49. Lockhart PB, Brennan MT, Sasser HC, Fox PC, Paster BJ, BahraniMougeot FK (2008) Bacteremia associated with toothbrushing and dental extraction. Circulation 117:3118-3125. https://doi.org/10. 1161/CIRCULATIONAHA.107.758524
50. Lundberg K, Wegner N, Yucel-Lindberg T, Venables PJ (2010) Periodontitis in RA-the citrullinated enolase connection. Nat Rev Rheumatol 6:727-730. https://doi.org/10.1038/nrrheum.2010.139

51. Malm S, Jusko M, Eick S, Potempa J, Riesbeck K, Blom AM (2012) Acquisition of complement inhibitor serine protease factor $\mathrm{I}$ and its cofactors $\mathrm{C} 4 \mathrm{~b}$-binding protein and factor $\mathrm{H}$ by Prevotella intermedia. PLoS One 7:e34852. https://doi.org/10.1371/journal. pone. 0034852

52. Miller DP, Bell JK, McDowell JV, Conrad DH, Burgner JW, Heroux A, Marconi RT (2012) Structure of factor H-binding protein $\mathrm{B}(\mathrm{FhbB})$ of the periopathogen, Treponema denticola: insights into progression of periodontal disease. J Biol Chem 287:1271512722. https://doi.org/10.1074/jbc.M112.339721

53. Naggara ON, Lecler A, Oppenheim C, Meder JF, Raymond J (2012) Endovascular treatment of intracranial unruptured aneurysms: a systematic review of the literature on safety with emphasis on subgroup analyses. Radiology 263:828-835. https://doi.org/10. 1148/radiol.12112114

54. Nieuwkamp DJ, Setz LE, Algra A, Linn FH, de Rooij NK, Rinkel GJ (2009) Changes in case fatality of aneurysmal subarachnoid haemorrhage over time, according to age, sex, and region: a metaanalysis. Lancet Neurol 8:635-642. https://doi.org/10.1016/S14744422(09)70126-7

55. Ollikainen E, Tulamo R, Frosen J, Lehti S, Honkanen P, Hernesniemi J, Niemela M, Kovanen PT (2014) Mast cells, neovascularization, and microhemorrhages are associated with saccular intracranial artery aneurysm wall remodeling. J Neuropathol Exp Neurol 73:855-864. https://doi.org/10.1097/NEN. 0000000000000105

56. Ollikainen E, Tulamo R, Lehti S, Hernesniemi J, Niemela M, Kovanen PT, Frosen J (2018) Myeloperoxidase associates with degenerative remodeling and rupture of the saccular intracranial aneurysm Wall. J Neuropathol Exp Neurol 77:461-468. https:// doi.org/10.1093/jnen/nly028

57. Ollikainen E, Tulamo R, Kaitainen S, Honkanen P, Lehti S, Liimatainen T, Hernesniemi J, Niemela M, Kovanen PT, Frosen J (2018) Macrophage infiltration in the saccular intracranial aneurysm wall as a response to locally lysed erythrocytes that promote degeneration. J Neuropathol Exp Neurol 77:890-903. https://doi. org/10.1093/jnen/nly068

58. Orlandi M, Suvan J, Petrie A, Donos N, Masi S, Hingorani A, Deanfield J, D'Aiuto F (2014) Association between periodontal disease and its treatment, flow-mediated dilatation and carotid intima-media thickness: a systematic review and meta-analysis. Atherosclerosis 236:39-46. https://doi.org/10.1016/j. atherosclerosis.2014.06.002

59. Paster BJ, Boches SK, Galvin JL, Ericson RE, Lau CN, Levanos VA, Sahasrabudhe A, Dewhirst FE (2001) Bacterial diversity in human subgingival plaque. J Bacteriol 183:3770-3783. https:// doi.org/10.1128/JB.183.12.3770-3783.2001

60. Popadiak K, Potempa J, Riesbeck K, Blom AM (2007) Biphasic effect of gingipains from Porphyromonas gingivalis on the human complement system. J Immunol 178:7242-7250

61. Potempa M, Potempa J, Okroj M, Popadiak K, Eick S, Nguyen KA, Riesbeck K, Blom AM (2008) Binding of complement inhibitor $\mathrm{C} 4 \mathrm{~b}$-binding protein contributes to serum resistance of Porphyromonas gingivalis. J Immunol 181:5537-5544

62. Potempa M, Potempa J, Kantyka T, Nguyen KA, Wawrzonek K, Manandhar SP, Popadiak K, Riesbeck K, Eick S, Blom AM (2009) Interpain $\mathrm{A}$, a cysteine proteinase from Prevotella intermedia, inhibits complement by degrading complement factor C3. PLoS Pathog 5:e1000316. https://doi.org/10.1371/journal.ppat.1000316

63. Pussinen PJ, Alfthan G, Jousilahti P, Paju S, Tuomilehto J (2007) Systemic exposure to Porphyromonas gingivalis predicts incident stroke. Atherosclerosis 193:222-228 
64. Pyysalo MJ, Pyysalo LM, Pessi T, Karhunen PJ, Ohman JE (2013) The connection between ruptured cerebral aneurysms and odontogenic bacteria. J Neurol Neurosurg Psychiatry 84:12141218. https://doi.org/10.1136/jnnp-2012-304635

65. Pyysalo MJ, Pyysalo LM, Pessi T, Karhunen PJ, Lehtimaki T, Oksala N, Ohman JE (2016) Bacterial DNA findings in ruptured and unruptured intracranial aneurysms. Acta Odontol Scand 74: 315-320. https://doi.org/10.3109/00016357.2015.1130854

66. Pyysalo MJ, Pyysalo LM, Hiltunen J, Jarnstedt J, Helminen M, Karhunen PJ, Pessi T (2018) The dental infections in patients undergoing preoperative dental examination before surgical treatment of saccular intracranial aneurysm. BMC Res Notes 11:600-z. https://doi.org/10.1186/s13104-018-3704-z

67. Rafferty B, Jonsson D, Kalachikov S, Demmer RT, Nowygrod R, Elkind MS, Bush H Jr, Kozarov E (2011) Impact of monocytic cells on recovery of uncultivable bacteria from atherosclerotic lesions. J Intern Med 270:273-280. https://doi.org/10.1111/j.1365-2796. 2011.02373.x

68. Razavian M, Bordenave T, Georgiadis D, Beau F, Zhang J, Golestani R, Toczek J, Jung JJ, Ye Y, Kim HY, Han J, Dive V, Devel L, Sadeghi MM (2016) Optical imaging of MMP-12 active form in inflammation and aneurysm. Sci Rep 6:38345. https://doi. org $/ 10.1038 /$ srep38345

69. Reyes L, Herrera D, Kozarov E, Rolda S, Progulske-Fox A (2013) Periodontal bacterial invasion and infection: contribution to atherosclerotic pathology. J Periodontol 84:30. https://doi.org/10.1902/ jop.2013.1340012

70. Rinkel GJ, Djibuti M, Algra A, van Gijn J (1998) Prevalence and risk of rupture of intracranial aneurysms: a systematic review. Stroke 29:251-256

71. Sahingur SE, Xia XJ, Alamgir S, Honma K, Sharma A, Schenkein HA (2010) DNA from Porphyromonas gingivalis and Tannerella forsythia induce cytokine production in human monocytic cell lines. Mol Oral Microbiol 25:123-135. https://doi.org/10.1111/j. 2041-1014.2009.00551.x

72. Sahingur SE, Xia XJ, Schifferle RE (2012) Oral bacterial DNA differ in their ability to induce inflammatory responses in human monocytic cell lines. J Periodontol 83:1069-1077. https://doi.org/ 10.1902/jop.2011.110522

73. Shikata F, Shimada K, Sato H, Ikedo T, Kuwabara A, Furukawa H, Korai M, Kotoda M, Yokosuka K, Makino H, Ziegler EA, Kudo D, Lawton MT, Hashimoto T (2019) Potential influences of gut microbiota on the formation of intracranial aneurysm. Hypertension 73:491496. https://doi.org/10.1161/HYPERTENSIONAHA.118.11804

74. Shimada K, Furukawa H, Wada K, Korai M, Wei Y, Tada Y, Kuwabara A, Shikata F, Kitazato KT, Nagahiro S, Lawton MT, Hashimoto T (2015) Protective role of peroxisome proliferatoractivated receptor-gamma in the development of intracranial aneurysm rupture. Stroke 46:1664-1672. https://doi.org/10.1161/ STROKEAHA.114.007722

75. Signorelli F, Sela S, Gesualdo L, Chevrel S, Tollet F, Pailler-Mattei C, Tacconi L, Turjman F, Vacca A, Schul DB (2018) Hemodynamic stress, inflammation, and intracranial aneurysm development and rupture: a systematic review. World Neurosurg 115:234-244

76. Slocum C, Coats SR, Hua N, Kramer C, Papadopoulos G, Weinberg EO, Gudino CV, Hamilton JA, Darveau RP, Genco CA (2014) Distinct lipid a moieties contribute to pathogen-induced site-specific vascular inflammation. PLoS Pathog 10:e1004215. https://doi.org/10.1371/journal.ppat.1004215

77. Socransky SS, Haffajee AD (2005) Periodontal microbial ecology. Periodontol 2000 38:135-187

78. Stegmayr B, Eriksson M, Asplund K (2004) Declining mortality from subarachnoid hemorrhage: changes in incidence and case fatality from 1985 through 2000. Stroke 35:2059-2063. https://doi. org/10.1161/01.STR.0000138451.07853.b6
79. Suzuki J, Aoyama N, Aoki M, Tada Y, Wakayama K, Akazawa H, Shigematsu K, Hoshina K, Izumi Y, Komuro I, Miyata T, Hirata Y, Isobe M (2014) High incidence of periodontitis in Japanese patients with abdominal aortic aneurysm. Int Heart J 55:268-270

80. Suzuki H, Mikami T, Tamada T, Ukai R, Akiyama Y, Yamamura A, Houkin K, Mikuni N (2019) Inflammation promotes progression of thrombi in intracranial thrombotic aneurysms. Neurosurg Rev. https://doi.org/10.1007/s10143-019-01184-3

81. Tamaki N, Tomofuji T, Ekuni D, Yamanaka R, Yamamoto T, Morita M (2009) Short-term effects of non-surgical periodontal treatment on plasma level of reactive oxygen metabolites in patients with chronic periodontitis. J Periodontol 80:901-906. https://doi. org/10.1902/jop.2009.080640

82. Tamaki N, Tomofuji T, Ekuni D, Yamanaka R, Morita M (2011) Periodontal treatment decreases plasma oxidized LDL level and oxidative stress. Clin Oral Investig 15:953-958. https://doi.org/10. 1007/s00784-010-0458-y

83. Tanner A, Maiden MF, Macuch PJ, Murray LL, Kent RL Jr (1998) Microbiota of health, gingivitis, and initial periodontitis. J Clin Periodontol 25:85-98

84. Tomas I, Diz P, Tobias A, Scully C, Donos N (2012) Periodontal health status and bacteraemia from daily oral activities: systematic review/meta-analysis. J Clin Periodontol 39:213-228. https://doi. org/10.1111/j.1600-051X.2011.01784.x

85. Tonetti MS, D'Aiuto F, Nibali L, Donald A, Storry C, Parkar M, Suvan J, Hingorani AD, Vallance P, Deanfield J (2007) Treatment of periodontitis and endothelial function. N Engl J Med 356:911-920

86. Tulamo R, Frosen J, Junnikkala S, Paetau A, Pitkaniemi J, Kangasniemi M, Niemela M, Jaaskelainen J, Jokitalo E, Karatas A, Hernesniemi J, Meri S (2006) Complement activation associates with saccular cerebral artery aneurysm wall degeneration and rupture. Neurosurgery 59:1069-1067. https://doi.org/10.1227/01. NEU.0000245598.84698.26

87. Tulamo R, Frosen J, Paetau A, Seitsonen S, Hernesniemi J, Niemela M, Jarvela I, Meri S (2010) Lack of complement inhibitors in the outer intracranial artery aneurysm wall associates with complement terminal pathway activation. Am J Pathol 177:3224-3232. https:// doi.org/10.2353/ajpath.2010.091172

88. Tulamo R, Frosen J, Hernesniemi J, Niemela M (2010) Inflammatory changes in the aneurysm wall: a review. J Neurointerv Surg 2:120-130. https://doi.org/10.1136/jnis.2009.002055

89. Turunen SP, Kummu O, Wang C, Harila K, Mattila R, Sahlman M, Pussinen PJ, Horkko S (2015) Immunization with malondialdehyde-modified low-density lipoprotein (LDL) reduces atherosclerosis in LDL receptor-deficient mice challenged with Porphyromonas gingivalis. Innate Immun 21:370-385. https://doi. org/10.1177/1753425914542444

90. Velsko IM, Chukkapalli SS, Rivera MF, Lee JY, Chen H, Zheng D, Bhattacharyya I, Gangula PR, Lucas AR, Kesavalu L (2014) Active invasion of oral and aortic tissues by Porphyromonas gingivalis in mice causally links periodontitis and atherosclerosis. PLoS One 9: e97811. https://doi.org/10.1371/journal.pone.0097811

91. Vlak MH, Algra A, Brandenburg R, Rinkel GJ (2011) Prevalence of unruptured intracranial aneurysms, with emphasis on sex, age, comorbidity, country, and time period: a systematic review and meta-analysis. Lancet Neurol 10:626-636. https://doi.org/10. 1016/S1474-4422(11)70109-0

92. Wang M, Shakhatreh MA, James D, Liang S, Nishiyama S, Yoshimura F, Demuth DR, Hajishengallis G (2007) Fimbrial proteins of porphyromonas gingivalis mediate in vivo virulence and exploit TLR2 and complement receptor 3 to persist in macrophages. J Immunol 179:2349-2358

Publisher's note Springer Nature remains neutral with regard to jurisdictional claims in published maps and institutional affiliations. 